\title{
PENGARUH TINGKAT INFLASI, INVESTASI, PERTUMBUHAN EKONOMI DAN TINGKAT PENGANGGURAN TERHDAP TINGKAT KEMISKINAN DI PROVINSI SULAWESI UTARA
}

\author{
Meinny Kolibu, Vekie A. Rumate, Daisy S.M. Engka \\ Fakultas Ekonomi dan Bisnis, Magister Ilmu Ekonomi \\ Universitas Sam Ratulangi
}

\begin{abstract}
ABSTRAK
Prioritas utama pembangunan di Sulawesi Utara saat ini adalah untuk mengentaskan kemiskinan.Salah satu permasalahan pokok Sulawesi Utara dalam Rencana Pembangunan Jangka Menengah Daerah (RPJMD) Sulawesi Utara adalah penanggulangan kemiskinan dan penggangguran. Penelitian ini bertujuan untuk mengetahui pengaruh tingkat inflasi, investasi, pertumbuhan ekonomi dan pengangguran terhadap tingkat kemiskinan di Sulawesi Utara dengan menggunakan metode analisis deskriptif dan analisis statistic inferensia untuk pengolahan data. Penelitian dilaksanakan di Provinsi Sulawesi utara.Hasil Penelitian menunjukkan bahwa Tingkat inflasi tidak memiliki pengaruh terhadap tingkat kemiskinan di Sulawesi Utara. Investasi memiliki pengaruh yang signifikan terhadap tingkat kemiskinan di Sulawesi Utara. Pengaruh investasi terhadap tingkat kemiskinan adalah bersifat positif, yang berarti jika investasi meningkat maka tingkat kemiskinan juga akan meningkat. Hal ini mengandung arti bahwa investasi, inflasi, pertumbuhan ekonomi dan pengangguran di Sulut tidak mampu menurunkan tingkat kemiskinan. Berdasarkan hasil penelitian disarankan bahwa Investasi harus memihak kepada kepentingan. Meskipun tingkat inflasi tidak berpengaruh terhadap tingkat kemiskinan namun pemerintah harus tetap mengontrol dan menjaga tingkat inflasi. Pertumbuhan ekonomi tetap harus dipacu pertumbuhannya. Tingkat pengangguran harus diturunkan setiap periodenya.
\end{abstract}

Kata Kunci : Tingkat Inflasi, Investasi, Pertumbuhan Ekonomi, Pengangguran dan Kemiskinan

\begin{abstract}
The main priority of development in North Sulawesi today is to alleviate poverty. One of North Sulawesi's main problems in the North Sulawesi Medium-Term Development Plan (RPJMD) is poverty alleviation and unemployment.This study aims to determine the effect of inflation rate, investment, economic growth and unemployment to the level of poverty in North Sulawesi by using descriptive analysis methods and inferential statistical analysis for data processing. The study was conducted in North Sulawesi Province. The results showed that inflation rate had no effect on poverty level in North Sulawesi. Investment has a significant influence on poverty levels in North Sulawesi. The effect of investment on poverty level is positive, which means that if investment increases then poverty level will also increase. This implies that investment, inflation, economic growth and unemployment in North Sulawesi can not reduce poverty. Based on the results of the study, it is suggested that Investment should be in favor of the interests. Although the inflation rate does not affect the level of poverty but the government must keep control and maintain the inflation rate. Economic growth should still be spurred by growth. The unemployment rate should be lowered each period.
\end{abstract}

Keywords: Inflation Rate, Investment, Economic Growth, Unemployment and Poverty 


\section{PENDAHULUAN}

\section{Latar Belakang}

Kemiskinan merupakan masalah sosial yang senantiasa hadir di tengah tengah masyarakat, khususnya di negara-negara yang sedang berkembang. Kemiskinan senantiasa menarik perhatian berbagai kalangan, baik para akademisi maupun para praktisi. Berbagai teori, konsep dan pendekatan pun terus menerus dikembangkan untuk menyibak tirai dan misteri kemiskinan ini. Di Indonesia masalah kemiskinan merupakan masalah sosial yang senantiasa relevan untuk dikaji terus-menerus. Masalah kemiskinan ini bukannya semakin berkurang, tetapi justru semakin bertambah jumlahnya.

Kemiskinan di Indonesia merupakan salah satu penyakit dalam ekonomi, sehingga harus ada solusi atau kebijakan untuk mengurangi tingkat kemiskinan. Masalah kemiskinan merupakan masalah yang rumit dan kompleks serta bersifat multidimensional. Oleh karena itu kebijakan yang dibuat untuk pengentasan yang dibuat pun harus dilakukan secara menyeluruh dan terpadu.

Kemiskinan adalah keadaan dimana terjadi ketidakmampuan untuk memenuhi kebutuhan dasar seperti makanan, pakaian, tempat berlindung, pendidikan, dan kesehatan. Kemiskinan dapat disebabkan oleh kelangkaan alat pemenuh kebutuhan dasar, ataupun sulitnya akses terhadap pendidikan dan pekerjaan. Kemiskinan merupakan masalah global. Sebagian orang memahami istilah ini secara subyektif dan komparatif, sementara yang lainnya melihatnya dari segi moral dan evaluatif, dan yang lainnya lagi memahaminya dari sudut ilmiah yang telah mapan, dan lain-lain. Kemiskinan merupakan masalah kompleks yang dipengaruhi oleh berbagai faktor yang saling berkaitan, antara lain: tingkat pendapatan, kesehatan, pendidikan, akses terhadap barang dan jasa, lokasi, geografis, gender, dan kondisi lingkungan. Mengacu pada strategi nasional penanggulangan kemiskinan definisi kemiskinan adalah kondisi di mana seseorang atau sekelompok orang, laki-laki dan perempuan, tidak terpenuhi hak-hak dasarnya untuk mempertahankan dan mengembangkan kehidupan yang bermartabat. Kemiskinan adalah kondisi dimana seseorang atau keluarga tidak mampu memenuhi kebutuhan primer. Negara Indonesia subur dan kekayaan alamnya melimpah, namun rakyatnya yang tergolong miskin cukup besar. Usaha Pemerintah dalam hal upaya untuk penanggulangan kemiskinan sangatlah serius, bahkan program penanggulangan kemiskinan merupakan salah satu program prioritas yang direncanakan oleh pemerintah. Menurut Tambunan (2003), masalah besar dalam pembangunan yang di hadapi banyak Negara berkembang termasuk Indonesia adalah kemiskinan atau jumlah orang yang berada dibawah garis kemiskinan (poverty line). Pembangunan di Indonesia saat ini telah membawa banyak perubahan dalam berbagai aspek di masyarakat, baik pada kawasan pedesaan maupun perkotaan. Perubahan tersebut membawa dampak tidak hanya terhadap lingkungan fisik, tapi juga sistem nilai dalam tatanan kehidupan sosial bermasyarakat. Namun sayangnya perubahan yang diciptakan oleh pembangunan membawa dampak yang menyertainya sangat mengerikan dan kompleks, karena ternyata telah melahirkan keterbelakangan dan kemiskinan dalam masyarakat. Selain kemiskinan, masalah pengangguran merupakan masalah yang tidak pernah habis untuk diperbincangkan. Pengangguran atau tuna karya adalah istilah bagi orang yang tidak bekerja sama sekali, sedang mencari pekerjaan atau seorang yang sedang berusaha mendapat pekerjaan yang layak. Pengangguran dapat diartikan sebagai seseorang yang telah mencapai usia tertentu yang tidak memiliki pekerjaan dan sedang mencari pekerjaan agar memperoleh upah atau keuntungan. Pengangguran umumnya disebabkan karena jumlah angkatan kerja atau para pencari kerja tidak sebanding dengan jumlah lapangan kerja yang ada (Sukirno,2004:327). 
Pertumbuhan ekonomi yang pesat tidak secara otomatis berdampak terhadap menurunnya tingkat kemiskinan di suatu negara. Sementara pada tahun 1960-an, pertumbuhan ekonomi tidak memberikan pengaruh yang berarti terhadap pengurangan tingkat kemiskinan. Namun pertumbuhan ekonomi tidak selalu diringi dengan penurunan jumlah penduduk miskin yang signifikan. Dalam program pembangunan pengentasan kemiskinan, selalu ada proses komunikasi ekonomi harus berfokus untuk mengurangi mekanisme yang membuat keluarga, daerah dan bahkan Negara secara keseluruhan terus berada dalam perangkap kemiskinan yakni ketika kemiskinan di masa lalu menyebabkan kemiskinan di masa depan dan menghasilkan strategi paling efektif untuk melepaskan diri dari perangkap itu (Todaro, 2011;10) yang sering disebut dengan sosialisasi melalui berbagai saluran informasi Ilmu pembangunan. Menurut M Kuncoro, 2003 suatu perekonomian dikatakan mengalami pertumbuhan atau berkembang apabila tingkat kegiatan ekonomi lebih tinggi dari apa yang dicapai sebelumnya. Dengan adanya pertumbuhan ekonomi yang semakin meningkat maka sebuah Negara dapat mencapai kemakmuran dan kesejahtraan ekonomi. Semakin meningkatnya pertumbuhan ekonomi menggambarkan bahwa semakin meningkatnya produksi Negara tersebut, sehingga masyarakat bisa memenuhi kebutuhan sehari-hari dengan cepat. Dan peningkatan pertumbuhan ekonomi ini dapat mengurangi kemiskinan di suatu Negara.

Pembangunan ekonomi atau lebih tepatnya pertumbuhan ekonomi merupakan prasyarat bagi terciptanya pembangunan manusia. Melalui pembangunan ekonomi akan dapat ditingkatkan produktivitas dan pendapatan penduduk dengan penciptaan kesempatan kerja. Menurut Todaro $(2008 ; 8)$ perbangunan ekonomi merupakan suatu proses multi dimensi yang mencakup berbagai berbagai perubahan dasar atau struktur sosial. Strategi pembangunan ekonomi adalah untuk meningkatkan output dari sektor pertanian, penciptaan lapangan kerja dan menuntaskan kemiskinan. Seperti yang kita ketahui, tingginya angka pengangguran, masalah ledakan penduduk, distribusi pendapatan yang tidak merata, dan berbagai masalah lainnya menjadi salah faktor utama rendahnya taraf hidup penduduk di Negara kita. Menurut Boediono (2001:35) pertumbuhan ekonomi adalah proses kenaikan output perkapita dalam jangka panjang. Pertumbuhan ekonomi merupakan indikator untuk melihat keberhasilan pembangunan dan merupakan syarat keharusan bagi penurunan pengangguran.

Inflasi yang merupakan variabel makro ekonomi selain pertumbuhan dan pengangguran semestinya mendapatkan perhatian penuh dari Pemerintah dalam hal menjaga tingkat kestabilannya. Setelah dahsyatnya goncangan krisis finansial (1998) yang merembet pada krisis kepercayaan, ekonomi Indonesia mulai bergerak dan bangkit kembali.

\section{Rumusan Masalah}

Berdasarkan latar belakang yang telah diuraikan, maka penelitian ini membahas pengaruh tingkat inflasi, investasi, pertumbuhan ekonomi, dan tingkat pengangguran terhadap tingkat kemiskinan di Sulawesi Utara. Oleh sebab itu, masalah dalam penulisan ini dirumuskan sebagai berikut:

1. Apakah tingkat inflasi memiliki pengaruh terhadap tingkat kemiskinan di Sulawesi Utara ?

2. Apakah investasi memiliki pengaruh terhadap tingkat kemiskinan di Sulawesi Utara ?

3. Apakah pertumbuhan ekonomi memiliki pengaruh terhadap tingkat kemiskinan di Sulawesi Utara?

4. Apakah tingkat pengangguran memiliki pengaruh terhadap tingkat kemiskinan di Sulawesi Utara?

5. Apakah tingkat inflasi, investasi, pertumbuhan ekonomi dan tingkat pengangguran secara bersama-sama memiliki pengaruh terhadap tingkat kemiskinan di Sulawesi Utara? 


\section{Tujuan Penelitian}

Tujuan dari dilakukannya penelitian ini adalah:

1. Untuk mengetahui pengaruh tingkat inflasi terhadap tingkat kemiskinan di Sulawesi Utara

2. Untuk mengetahui pengaruh investasi terhadap tingkat kemiskinan di Sulawesi Utara.

3. Untuk mengetahui pengaruh pertumbuhan ekonomi terhadap tingkat kemiskinan di Sulawesi Utara.

\section{Manfaat Penelitian}

Hasil penelitian ini diharapkan dapat memberikan manfaat untuk :

1) Pemerintah, sebagai salah satu referensi mengenai betapa pentingnya menjaga laju inflasi dan investasi serta meningkatkan pertumbuhan ekonomi sehingga dapat dijadikan suatu acuan untuk menetapkan kebijakan dalam rangka mengatasi masalah pengangguran dan penanggulangan kemiskinan di Indonesia.

2) Investor/Pengusaha hasil penelitian ini dapat digunakan sebagai informasi dan menjadi bahan masukan untuk pertimbangan dan evaluasi pada saat menanamkan modal di Sulawesi Utara.

3) Bagi dunia akademis, penelitaian dapat dipakai sebagai bahan referensi perpustakan, untuk referensi perbandingan terhadap objek penelitian yang sama.

\section{Kemiskinan}

\section{LANDASAN TEORI}

Kemiskinan merupakan fenomena yang sering dijumpai dalam kehidupan bermasyarakat. Otonomi daerah membawa suatu kesempatan besar bagi pemerintah daerah untuk menyelenggarakan keuangan daerahnya dengan lebih baik. Pengelolaan keuangan daerah harus memberikan dampak yang signifikan terhadap pembangunan di daerah, terutama dalam meningkatkan pertumbuhan ekonomi, menurunkan jumlah pengangguran dan menurunkan tingkat kemiskinan. Menurut para ahli (Andre Bayo Ala: 1981) kemiskinan bersifat multidimensional artinya kebutuhan manusia itu bermacam-macam, maka kemiskinan pun memiliki banyak aspek.

Badan Perencana Pembangunan Nasional (2004 ) menjelaskan kemiskinan adalah situasi serba kekurangan yang terjadi karena bukan karena dikehendaki oleh si miskin, melainkan tidak dapat dihindari dengan kekuatan yang ada padanya.

\section{Inflasi}

Inflasi merupakan kenaikan didalam tingkat harga umum (Samuelson dan Nordhaus, 2004). Secara sederhana inflasi diartikan sebagai meningkatnya harga-harga secara umum dan terus-menerus. Kenaikan harga dari satu atau dua barang saja tidak dapat disebut inflasi kecuali bila kenaikan itu meluas (atau mengakibatkan kenaikan harga ) pada barang lainnya.

Ada beberapa faktor yang menjadi penyebab terjadinya inflasi antara lain penurunan nilai tukar mata uang, permintaan yang tinggi terhadap suatu barang, bertambahnya uang yang beredar, dan lain sebagainya.

- Inflasi karena permintaan (Demand Pull Inflation)

- Inflasi karna bertambahnya uang beredar

- Inflasi karna kenaikan biaya produksi (Cost push inflation) 
- Inflasi Campuran (Mixed Inflation)

- Inflasi ekspektasi (Expected Inflation)

- Kekacauan ekonomi dan politik

$>$ Teori Kuantitas

Menurut teori ini, inflasi disebabkan oleh jumlah uang beredar dan psikologi (harapan) masyarakat mengenai kenaikan harga di masa datang.

\section{$>$ Teori Keynes}

Menurut Keynes, inflasi terjadi karena masyarakat ingin hidup di luar batas kemampuannya

(secara ekonomis).

\section{$>$ Teori Strukturalis}

Teori ini memberikan tekanan pada kekuatan dari struktur perekonomian seperti yang terjadi

di Negara-negara berkembang.

\section{Investasi}

Menurut Sukirno (2004:435) pengertian investasi yaitu pengeluaran atau pembelanjaan penanaman modal atau perusahaan untuk membeli barang-barang modal dan perlrngkapan produksi unuk menambah kemampuan memproduksi barang dan jasa yang tersedia dalam perekonomian. Pengertian lain dari investasi adalah suatu aktiva yang digunakan perusahaan untuk pertumbuhan kekayaan melalui distribusi hasil investasi (seperti pendapatan bunga, "royalty", deviden, pendapatan sewa dan lain-lain), untuk apresiasi nilai investasi, atau untuk manfaat lain bagi perusahaan yang berinvestasi, seperti manfaat yang diperoleh melalui hubungan dagang. Investasi adalah suatu komponen dari PDB dengan rumus $\mathrm{PDB}=\mathrm{C}+\mathrm{I}+\mathrm{G}$ (X-M). Peran investasi di Sulut sangat berperan besar dalam menumbuhkan perekonomian di daerah karena multiplier effek dari investasi akan meningkatkan produktiitas, memacu perumbuhan dan berpeluang meningkatkan pendapatan masyarakat dan mengurangi kemiskinan.

\section{Pertumbuhan Ekonomi}

Pertumbuhan ekonomi merupakan salah satu indikator untuk melihat hasil pembangunan yang telah dilakukan dan juga berguna untuk menentukan arah pembangunan dimasa yang akan datang. Pertumbuhan Ekonomi mutlak harus ada sehingga pendapatan masyarakat akan bertambah, dengan demikian tingkat kesejahtraan masyarakat diharapkan akan meningkat. Simon Kuznets dalam Todaro (2000:115) menyatakan bahwa " a country's economic growth as long term rise in capacity to supply increasing diverse economic goods to it's population, this growing capacity based on advancing technology and the institutional and ideology adjustment that it demand."

\section{Pengangguran}

Penggangguran adalah masalah makro ekonomi yang mempengaruhi manusia secara langsung. Bagi kebanyakan orang kehilangan pekerjaan berarti penurunan standard kehidupan dan rekanan psikologis. Jadi tidaklah mengejutkan jika pengganguran menjadi topik yang sering dibicarakan dalam perdebatan politik dan para politisi sering mengklaim bahwa kebijakan yang mereka tawarkan akan membantu menciptakan lapangan kerja (Mankiw, 2003:150). 


\section{Hubungan pertumbuhan ekonomi terhadap kemiskinan}

Dasar teori dari korelasi antara pertumbuhan pendapatan per kapita dan tingkat kemiskinan tidak berbeda dengan kasus pertumbuhan ekonomi dengan ketimpangan dalam distribusi pendapatan. Mengikuti hipotesis Kuznets, pada tahap awal dari proses pembangunan, tingkat kemiskinan cenderung meningkat, dan pada saat mendekati tahap akhir dari pembangunan jumlah orang miskin berangsur-angsur berkurang. Banyak faktor lain selain pertumbuhan pendapatan yang juga berpengaruh terhadap tingkat kemiskinan di suatu wilayah/Negara, seperti derajat pendidikan tenaga kerja dan struktur ekonomi.

\section{Hubungan inflasi terhadap kemiskinan}

Inflasi dapat didefinisikan sebagai kecenderungan dari harga-harga untuk menaik secara umum dan terus menerus, atau bisa juga disebut gejala ketidak seimbangan antara jumlah uang yang beredar dengan jumlah barang dan jasa yang tersedia, jumlah uang yang beredar lebih besar dibanding dengan jumlah barang dan jasa yang tersedia. Menurut teori Keynes inflasi terjadi karena suatu masyarakat ingin hidup diluar batas kemampuan ekonominya. Dengan kata lain proses perebutan bagian rezeki diantara kelompok-kelompok sosial yang menginginkan bagian yang lebih besar daripada yang dapat disediakan masyarakat sehingga proses perebutan ini akhirnya diterjemahkan menjadi keadaan dimana permintaan masyarakat akan barang-barang selalu melebihi jumlah barang-barang yang tersedia (inflationary gap).

\section{Hubungan Investasi terhadap kemiskinan}

Menurut Sadono Sukirno (2000) kegiatan investasi memungkinkan suatu masyarakat terus menerus meningkatkan kegiatan ekonomi dan kesempatan kerja, meningkatkan pendapatan nasional dan meningkatkan taraf kemakmuran masyarakat. Peranan ini bersumber daritiga fungsi penting dari kegiatan investasi, yakni (1) investasi merupakan salah satu komponen dari pengeluaran agregat,

Sehingga kenaikan investasi akan meningkatkan permintaan agregat, pendapatan nasional serta kesempatan kerja; (2) pertambahan barang modal sebagai akibat investasi akan menambah kapasitas produksi; (3) investasi selalu diikuti oleh perkembangan teknologi.

\section{Hubungan pengangguran terhadap kemiskinan}

Pengangguran dapat diartikan sebagai seseorang yang tidak mempunyai pekerjaaan. permasalahan yang timbul ke permukaan berkaitan dengan pesatnya pertumbuhan penduduk adalah ketidakseimbangan antara pertumbuhan lapangan pekerjaan dengan semakin bertambahnya tenaga kerja setiap tahunnya. Hal ini akan menimbulkan kelebihan penawaran tenaga kerja dibandingkan dengan permintaannya. Sehingga fenomena ini memunculkan adanya pengangguran. Pengangguran

di satu sisi menunjukkan adanya selisih antara permintaan (demand for labor) dan penawaran tenaga kerja (supply of labor) dalam suatu perekonomian. Diluar itu terdapat juga sebab-sebab non ekonomis seperti pranata, sikap dan pola tingkah laku yang berhubungan dengan pengamanan hak kerja, serta keinginan si penganggur untuk menerima jenis pekerjaan yang lebih cocok dengan kualifikasi, aspirasi atau selera mereka. (Munir, 1985). 


\section{Kerangka Pemikiran Teoritis}

Berdasarkan penjelasan diatas, dapat digambarkan kerangka pemikiran mengenai Pengaruh tingkat inflasi, investasi dan pertumbuhan ekonomi dan pengangguran terhadap kemiskinan adalah sebagai berikut:

\section{Kerangka Pemikiran}

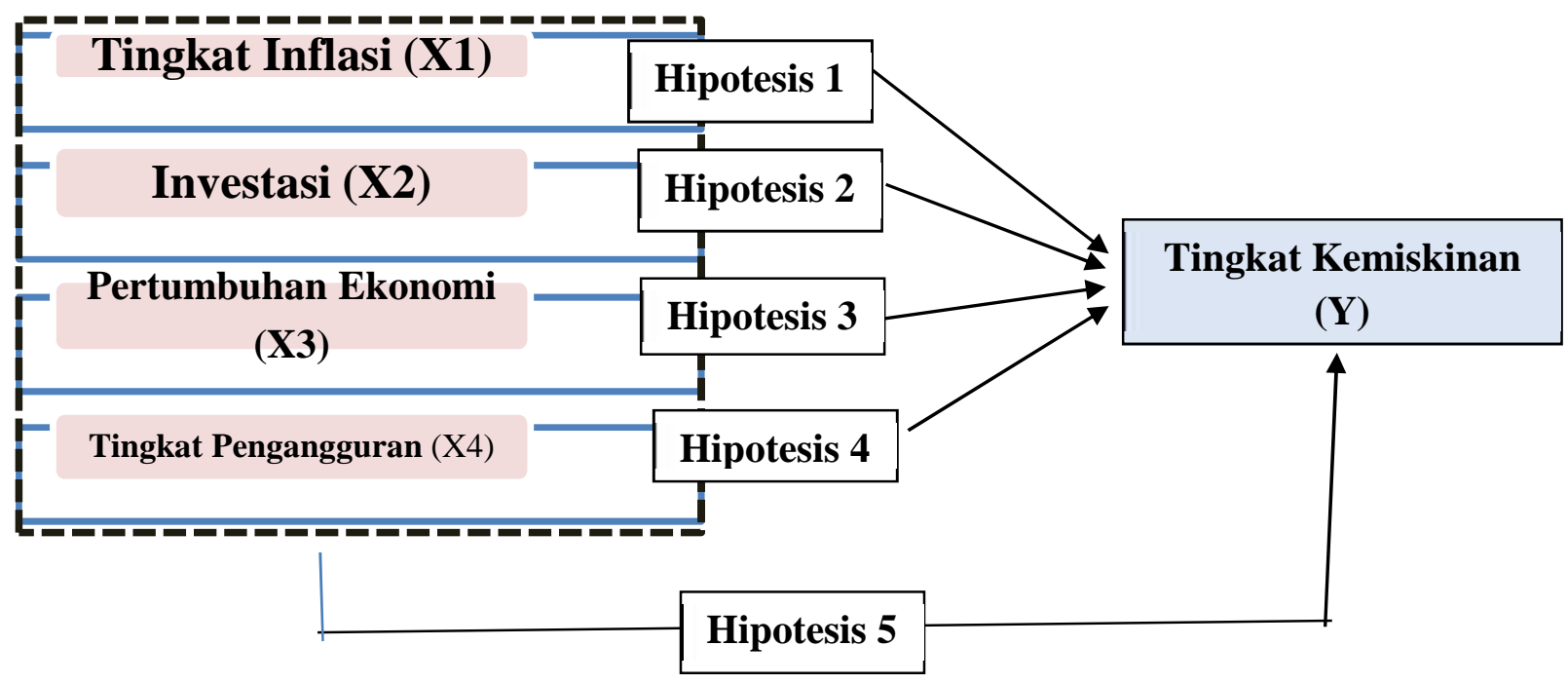

\section{Hipotesis :}

1. Diduga tingkat inflasi memiliki pengaruh terhadap tingkat kemiskinan di Sulawesi Utara.

2. Diduga investasi memiliki pengaruh terhadap tingkat kemiskinan di Sulawesi Utara.

3. Diduga pertumbuhan ekonomi memiliki pengaruh terhadap tingkat kemiskinan di Sulawesi Utara.

4. Diduga tingkat pengangguran memiliki pengaruh terhadap tingkat kemiskinan di Sulawesi Utara.

5. Diduga tingkat inflasi, investasi, pertumbuhan ekonomi dan tingkat pengangguran secara bersama-sama memiliki pengaruh terhadap tingkat kemiskinan di Sulawesi Utara.

\section{METODE PENELITIAN}

\section{Data dan Sumber Data}

Data analisis ini menggunakan data sekunder time series sejak tahun 2006-2015. Data sekunder yang dimaksud berupa data kemiskinan Provinsi Sulawesi Utara, data penduduk berdasarkan angkatan kerja, data inflasi, data investasi dan data pertumbuhan dan perkembangan Provinsi Sulawesi Utara dalam angka tahun 2006-2015 bersumber dari Bappeda Prov. Sulut, Dinas tenaga Kerja Prov. Sulut, Badan Penanaman Modal Prov. Sulut dan Biro Pusat Statisti (BPS) Prov. Sulut.

\section{Metode Analisis Data}

Metode analisis yang digunakan dalam penelitian ini adalah :

\section{○ Analisis Deskriptif}


Metode ini berupa metode analisa tabel yang bertujuan untuk mengkaji dan menganalisa perkembangan yang terjadi dalam perekonomian di Provinsi Sulawesi Utara secara umum dan lebih khusus lagi mengenai perkembangan tingkat inflasi, investasi, pertumbuhan ekonomi, pengangguran dan tingkat kemiskinan.

○ Analisis Statistik Inferensia

Analisis statistik yang digunakan adalah analisis regresi berganda dengan rumus sebagai berikut :

a. $\mathbf{Y}=\boldsymbol{\beta} 0+\boldsymbol{\beta} \mathbf{1 X 1}+\boldsymbol{\beta} 2 \times \mathbf{2}+\boldsymbol{\beta} 3 \times \mathbf{3}+\boldsymbol{\beta} 4 \mathbf{4} \mathbf{4}+\mathbf{e} ;$ dimana :

$\mathrm{Y}=$ Tingkat Kemiskinan(Variabel Terikat)

$\beta o=$ Konstanta

$\beta 1, \beta 2, \beta 3$ dan $\beta 4=$ Koefisien Regresi

$\mathrm{X} 1$ = Tingkat Inflasi (Variabel Bebas 1)

$\mathrm{X} 2$ = Investasi (Variabel Bebas 2)

$\mathrm{X} 3$ = Pertumbuhan Ekonomi (Variabel Bebas 3)

$\mathrm{X} 4$ = Pengangguran (Variabel Bebas 4)

$\mathrm{e}=$ Parameter Pengganggu

b. Koefiesien Determinasi Berganda $\left(\mathrm{R}^{2}\right)$ yakni besarnya proporsi atau sumbangan ketiga variabel bebas terhadap perubahanvariabel terikat dengan menggunakan rumus koefisien determinasi berganda yakni :

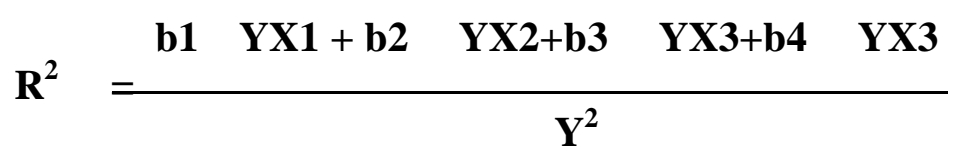

Nilai $\mathrm{R}^{2}$ terletak antara 0 dan 1 . Jika $\mathrm{R}^{2}=1$ berarti 100 persen total variasi veriabel terikat dijelaskan oleh variabel-variabel bebasnya dan menunjukkan ketepatan terbaik. Bila $\mathrm{R}^{2}=0$ berarti tak ada total variasi variabel terikat yang dijelaskan oleh variabel bebasnya (Wirawan, 2002 : 299-300).

c. Koefisien korelasi berganda (R) ; dalam regresi berganda nilai korelasi berganda selalu bernilai positif. Koefisien korelasi berganda digunakan untuk melihat keeratan hubungan antara variabel bebas secara bersama-sama terhadap variabel terikat.

Rumus yang digunakan adalah $: \mathbf{R}=\sqrt{ } \mathbf{R}^{2}$. Jika $\mathrm{R}=1$ berarti terdapat korelasi linier sempurna dan positif antara variabel bebas dengan variabel terikat . Jika $\mathrm{R}=-1$ maka terdapat korelasi linier sempurna dan negatif sedangkan jika $\mathrm{R}=0$ tidak ada korelasi antara variabel bebas dengan variabel terikat.

d. Uji signifiknasi secara individual (uji t) bertujuan untuk menguji apakah koefisien regresi parsial berbeda secara signifikan (nyata) dari 0 atau apakah suatu variabel bebas secara individu berpengaruh terhadap variabel terikatnya.

$$
\text { Rumusnya adalah : } \quad t=b i-\beta i \text { / Sbi }
$$

Hipotesis yang digunakan adalah:

Ho : $\beta_{i}=0$

Ha : $\beta_{i} \neq 0$

dengan menentukan derajat keyakinan $95 \%(\alpha=0,05)$

dimana :

Jika t-hitung $\leq$ t-tabel $\alpha / 2(\mathrm{n}-\mathrm{k})$ maka Ho di terima 
Jika t-hitung $\geq$ t-tabel $\alpha / 2$ (n-k) maka Ho di tolak

a. Uji signifikansi serempak (uji F) bertujuan untuk menguji apakah koefisien regresi parsial secara serempak atau bersama-sama berbeda secara signifikan dari 0 atau apakah ada pengaruh yang signifikan variabel bebas X1 dan X2 secara serempak terhadap variabel terikat $\mathrm{Y}$.

b. Rumusnya adalah : $\mathrm{F}=\mathrm{R}^{2} /(\mathrm{k}-1) /\left(1-\mathrm{R}^{2}\right) /(\mathrm{n}-\mathrm{k})$.

Hipotesis yang digunakan adalah: $\mathrm{H} 0: \beta 1=\beta 2=0$

$$
\mathrm{H} 1: \beta 1 \neq \beta 2 \neq 0
$$

\section{○ Uji Asumsi Klasik}

Uji Autokorelasi

Uji ini merupakan pengujian asumsi dalam regresi di mana variabel dependen tidak berkorelasi dengan dirinya sendiri. Maksud berkorelasi dengan dengan dirinya sendiri adalah bahwa nilai dari variabel dependen atau variabel terikat tidak berhubungan dengan nilai variabel itu sendiri, baik nilai periode sebelumnya atau nilai periode sesudahnya.

\section{Uji Multikolinearitas}

Asumsi multikolinieritas menyatakan bahwa variabel independen harus terbebas dari gejala multikolinieritas. Gejala multikolinearitas adalah gejala korelasi antar variabel independen. Gejala ini ditunjukkan dengan korelasi yang signifikan antar variabel independen. Dengan kata lain multikolinaeritas berarti adanya hubungan linear yang sempurna atau pasti diantara beberapa atau semua variabel yang menjelaskan dari model regresi.(Gujarati, 2005 : 157).

\section{Uji Heteroskedastisitas}

Salah satu asumsi dalam regresi linear klasik adalah bahwa gangguan (disturbance) ui yang muncul dalam fungsi regresi populasi adalah homoskedastik yaitu semua gangguan tadi mempunyai varians yang sama. (Gujarati 2005, : 177).

\section{○ Uji Normalitas Data}

Uji normalitas dilakukan untuk menguji apakah dalam model regresi, variabel penggangu atau residual memiliki distribusi normal.Model regresi yang baik adalah berdistribusi normal atau mendekati normal.

\section{HASIL PENELITIAN DAN PEMBAHASAN}

\section{Hasil Penelitian Uji Asumsi Klasik}

Uji asumsi klasik dalam penelitian ini menggunakan bantuan Software SPSS 17 hasilnya adalah sebagai berikut : 


\section{- Uji Auto Korelasi}

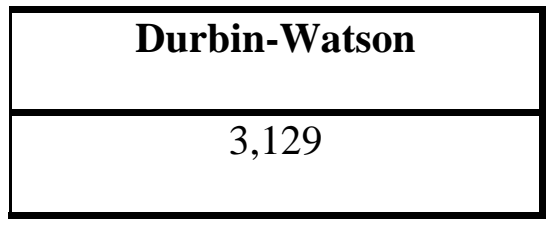

$\mathrm{H} 0$ = tidak ada serial autokorelasi baik positif maupun negatif. Jika 4-du $\leq \mathrm{d} \leq 4$-dl berarti pengujian tidak meyakinkan atau cenderung tidak ada masalah autokorelasi. (Gujarati 2005 : 218). $\mathrm{du}=1,97 \mathrm{dl}=0,69$ maka 4-1,97<3,146< $4-0,69$ sehingga 2,03<3,129<3,31. Berdasarkan hasil ini maka pengujian tidak meyakinkan atau cenderung tidak ada masalah autokorelasi.

- Uji Multikolinieritas

Collinearity Statistic

\begin{tabular}{|c|c|c|}
\hline \multirow{2}{*}{ Model } & \multicolumn{2}{|c|}{ Collinearity Statistics } \\
\cline { 2 - 3 } & Tolerance & VIF \\
\hline Tingkat Inflasi & 0,898 & 1,114 \\
\hline Investasi & 0,791 & 1,264 \\
\hline Pertumbuhan Ekonomi & 0,809 & 1,235 \\
\hline Tingkat Pengangguran & 0,739 & 1,353 \\
\hline
\end{tabular}

Hasil uji multikolinieritas menunjukkan bahwa nilai VIF dari variabel tingkat inflasi, investasi swasta, pertumbuhan ekonomi, dan tingkat inflasi adalah lebih kecil dari 10. Hal ini menunjukkan bahwa tidak terjadi gejala multikolineritas didalam variabel penelitian ini.

\section{- Uji Heteroskedastisitas}

Hasil uji heteroskedastisias memperlihatkan sebaran residual dalam scatterplot terpencar tidak beraturan atau tidak membentuk suatu pola tertentu yang rapi dan teratur. Oleh karena itu berdasarkan hal ini maka di dalam penelitian ini tidak terjadi gejala homokedastisitas atau persamaan memenuhi asumsi heterokedastisitas

\section{Uji Normalitas Data}

Uji normalitas data bertujuan untuk menguji data-data tentang variabel yang digunakan dalam penelitian ini apakah sudah tersebar secara normal atau tidak.Sebelum digunakan dalam model regresi berganda maka variabel-varibel penelitian perlu di uji kenormalan datanya.Asumsi yang digunakan adalah bahwa data peneltian adalah data yang tersebar secara normal atau tersebar mendekati sumbu regresi. Uji normalitas data dalam penelitian ini menggunakan Test 
Kolmogorov-Smirnov dengan Software Program SPSS 17. Hasil uji normalitas data adalah sebagai berikut:

\section{Hasil Uji Regresi Berganda dan Pengaruh Secara Parsial}

Coefficients

\begin{tabular}{|l|r|r|r|r|}
\hline \multirow{2}{*}{ Model } & \multicolumn{2}{|c|}{$\begin{array}{c}\text { Unstandardized } \\
\text { Coefficients }\end{array}$} & $\begin{array}{c}\text { Standardized } \\
\text { Coefficients }\end{array}$ & \multirow{2}{*}{ t } \\
\cline { 2 - 5 } & \multicolumn{1}{|c|}{ B } & Std. Error & \multicolumn{1}{c|}{ Beta } & \\
\hline (Constant) & 190.102 & 490.849 & & .387 \\
Tingkat Inflasi & -.023 & .074 & -.073 & -.308 \\
Investasi & .502 & .148 & .857 & 3.406 \\
Pertumbuhan Ekonomi & -.081 & .356 & -.057 & -.227 \\
Tingkat Pengangguran & .004 & .105 & .011 & .042 \\
\hline
\end{tabular}

Berdasarkan tabel diatas maka Persamaan Regresi dari penelitian ini adalah $\hat{Y}=190,102-$ 0,023 Tingkat Inflasi + 0,502 Investasi - 0,081 Pertumbuhan Ekonomi - 0,004 Tingkat Pengangguran.

Pengaruh Variabel Bebas terhadap Variabel Terikat secara Bersama-sama atau Simultan

Pengaruh tingkat inflasi, investasi swasta, pertumbuhan ekonomi, dan tingkat pengangguran secara bersama-sama terhadap tingkat kemiskinan di Sulawesi Utara dapat dilihat

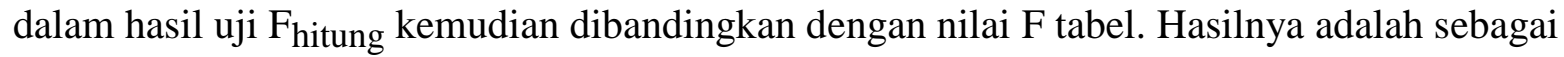
berikut :

\begin{tabular}{|c|c|c|c|c|c|c|}
\hline \multicolumn{7}{|c|}{ ANOVA $^{b}$} \\
\hline \multicolumn{2}{|c|}{ Model } & Sum of Squares & $\mathrm{df}$ & Mean Square & $\mathrm{F}$ & Sig. \\
\hline \multirow[t]{3}{*}{1} & Regression & 914905.597 & 4 & 228726.399 & \multirow[t]{3}{*}{.897} & \multirow[t]{3}{*}{$.529^{\mathrm{a}}$} \\
\hline & Residual & 1274409.303 & 5 & 254881.861 & & \\
\hline & Total & 2189314.900 & 9 & & & \\
\hline
\end{tabular}

a. Predictors: (Constant), Tingkat Pengangguran, Inflasi, Pertumbuhan Ekonomi, Investasi

b. Dependent Variable: Tingkat Kemiskinan

Berdasarkan tabel ANOVA tersebut diatas maka dapat dianalisa sebagai berikut:

- Nilai $F_{\text {hitung }}$ adalah sebesar 3,744 
- Nilai $\mathrm{F}_{\text {tabel }}$ untuk 4 variabel bebas $(\mathrm{k}=4)$ dengan $\mathrm{n}-\mathrm{k}(10-4)$ atau 4 variabel bebas dan $\mathrm{n}=$ 6 adalah 4,53

- Nilai Fhitung $(3,744)$ < Nilai F tabel $(4,53)$, dengan demikian maka secara bersama-sama atau simultan tingkat inflasi, investasi, pertumbuhan ekonomi dan tingkat pengangguran tidak memiliki pengaruh terhadap tingkat kemiskinan di Sulawesi Utara.

\section{Korelasi antara Variabel Bebas Dengan Variabel Terikat}

Korelasi atau keeratan hubungan antara variabel bebas dengan variabel terikat dapat dilihat dalam besarnya hasil uji korelasi yakni uji R :

\begin{tabular}{|c|c|c|}
\hline $\mathbf{R}$ & R Square & Adjusted R Square \\
\hline 0,866 & 0,750 & 0,549 \\
\hline
\end{tabular}

Hasil uji $\mathrm{R}$ menunjukkan bahwa keeratan hubungan antara laju inflasi, investasi swasta, pertumbuhan ekonomi, dan tingkat pengangguran sebagai variabel bebas dalam penelitian ini dengan tingkat kemiskinan sebagai variabel terikat adalah

0866 atau sebesar 86,6 persen. Hal ini berarti bahwa antara variabel bebas dengan variabel terikat terdapat hubungan yang erat dan bersifat positif.

\section{Kontribusi Variabel bebas terhadap Variabel Terikat}

Kontribusi atau determinasi variabel bebas terhadap variabel terikat dalam penelitian ini dpat diliaht dalam uji determinan $\left(R\right.$ Square atau $\left.\mathrm{R}^{2}\right)$. Hasil yang tercantum dalam tabel diatas menunjukkan bahwa nilai $\mathrm{R}$ Square adalah sebesar 0,750 atau $75 \%$. Hal ini berarti bahwa kontribusi laju inflasi, investasi swasta, pertumbuhan ekonomi dan tingkat pengangguran terhadap tingkat kemiskinan di Sulawesi Utara adalah sebesar $75 \%$ sedangkan sisanya sebesar $25 \%$ disumbangkan oleh variabel lain yang tidak dikaji dalam penelitian ini.

\section{Pembahasan}

Dari hasil penelitian yang dilakukan mendapatkan hasil secara parsial tingkat inflasi tidak berpengaruh terhadap tingkat kemiskinan hal ini tentunya tidak sejalan dengan hipotesis yang mengatakan bahwa tingkat inflasi memiliki pengaruh terhadap tingkat kemiskinan dan teori dimana inflasi berpengaruh positif bagi tingkat kemiskinan. Inflasi merupakan determinan makro ekonomi bagi perubahan kondisi kemiskinan disuatu Negara. Penduduk miskin tidak akan terpengaruh pada tingkat inflasi karena pada dasarnya penduduk miskin tidak mempunyai daya beli, sehingga walaupun terjadi inflasi mereka tetap tidak punya daya beli. Kebijakan pemerintah menaikkan harga BBM (Bahan Bakar Minyak) pada akhir Mei 2008 lalu telah mendorong meningkatnya tekanan inflasi khususnya dari sisi penawaran. Tercatat inflasi tahunan pada Juni 2008 meningkat tajam mencapai 13,18\%.

Hasil penelitian menyatakan bahwa secara parsial tingkat pengangguran tidak memiliki pengaruh terhadap tingkat kemiskinan. Dalam kasus ini hubungan antara pengangguran dan kemiskinan tidak selalu sesuai dengan asumsi teori ekomoni yang ada. Fenomena ini dapat dijelaskan bahwa ada orang yang menganggur dalam sebuah rumah tangga, tetapi ada anggota rumah tangga yang lain yang bekerja dengan tingkat pendapatan tinggi sehingga cukup untuk menyokong penganggur. Penganggur yang ada di dalam rumah tersebut tidak otomatis menjadi 
miskin. Fakta lain juga adanya pengangguran tersembunyi dengan rendahnya jam kerja riil, sehingga akan berakibat pada rendahnya produktivitas. Rendahnya produktivitas tenaga kerja selain ditentukan oleh jam kerja juga ditentukan oleh kualitas sumber daya manusia yang tercermin dari rendahnya tingkat pendidikan. Walaupun mereka bekerja (tidak menganggur), maka pendapatan yang diterima relatif rendah dan dibawah garis kemiskinan. Sehingga walaupun dengan tingkat pengangguran yang rendah, tingkat kemiskinan cukup tinggi. Fakta lain juga bisa terjadi, yaitu pada kelompok keluarga yang sangat miskin, justru tingkat pengangguran rendah. Pada kelompok keluarga miskin ini, sebagian besar anggota keluarga bekerja untuk bisa bertahan hidup, terkadang anak-anak juga dilibatkan dalam bekerja dengan alasan penghasilan kepala keluarga atau orang tua tidak mencukupi kebutuhan keluarga. Sehingga adanya kecenderungan tingkat pengangguran akan rendah. Karena tingkat pendidikan yang ditamatkan rendah maka tingkat upah ataupun penghasilan yang mereka terima sangat rendah dan dibawah garis kemiskinan. Sehingga walaupun dengan tingkat pengangguran yang rendah karena sebagian besar bekerja, namun mereka tetap miskin.

\section{Kesimpulan}

\section{KESIMPULAN DAN SARAN}

Berdasarkan hasil penelitian dan pembahasan maka dapat ditarik kesimpulan sebagai berikut :

1. Tingkat inflasi tidak memiliki pengaruh terhadap tingkat kemiskinan di Sulawesi Utara.

2. Investasi memiliki pengaruh yang signifikan terhadap tingkat kemiskinan di Sulawesi Utara.

3. Pertumbuhan ekonomi tidak memiliki pengaruh terhadap tingkat kemiskinan di Sulawesi Utara.

4. Tingkat pengangguran tidak memiliki pengaruh terhadap tingkat kemiskinan di Sulawesi Utara.

Tingkat inflasi, investasi, pertumbuhan ekonomi dan tingkat pengangguran secara bersamasama atau simultan tidak memiliki pengaruh terhadap tingkat kemiskinan di Sulawesi Utara.

\section{Saran}

1. Investasi harus memihak kepada kepentingan publik sehingga mampu memberika efek terhadap penurunan angka kemiskinan.

2. Meskipun tingkat inflasi tidak berpengaruh terhadap tingkat kemiskinan namun pemerintah harus tetap mengontrol dan menjaga tingkat inflasi agar kenaikan harga barang-barang terutama barang kebutuhan pokok dan bangunan tidak mengalami kenaiakan harga yang signifikan.

3. Pertumbuhan ekonomi tetap harus dipacu pertumbuhannya. Perlu diperhatikan kualitas pertumbuhan ekonomi di Sulawesi Utara sebab pertumbuhan ekonomi yang tinggi semestinya berpengaruh signifikan terhadap kemiskinan.

Tingkat pengangguran harus diturunkan setiap periodenya meskipun tidak memiliki pengaruh terhadp kemiskinan, namun dapat dipahami untuk jangka panjang jika pengangguran semakin tinggi maka akan berimbas pada penurunan pendapatan per kapita dan mengarah pada kemiskinan.

\section{DAFTAR PUSTAKA}

Bappenas, BPS, UNDP.(2004). "Laporan Pembangunan Manusia Indonesia 2004, Menuju Konsensus Baru Demokrasi dan pembangunan Manusia Di Indonesia", Bappenas, BPS, $U N D P$. Jakarta 
Boediono.(2001). Ekonomi Makro, Yogyakarta

Gujarati, Damodar.(2005). Ekonometrika Dasar, Alih Bahasa Sumarno Zain, Penerbit Erlangga, Jakarta

Mankiw N Gregori.2004. "Pengantar Ekonomi Makro" J akarta, Salemba Empat 2004 Edisi 3.

Samuelson, Paul A dan Nordhaus, William D. (2004). Ilmu Makro Ekonomi (gretta, Theresa Tanoto, Bosco Carvallo dan Anna Elly, Penerjemah). (17 ed) Jakarta PT. Media Global Edukasi

Santosa, PB, dan Ashari.2005. Analisis Statistik dengan Microsoft Excel dan SPSS, Penerbit ANDI, Yogyakarta

Sukirno, Sadono. 2000. Makroekonomi Teori Pengantar. PT. Raja Grafindo Persada, Jakarta.

Sukirno, Sadono. 2004. Makroekonomi Teori Pengantar. PT. Raja Grafindo Persada. Jakarta.

Tambunan, Tulus T.H.2003. Perekonomian Indonesia: beberapa permasalahan penting. Ghalia Indonesia. Bogor

Todaro, Michael P. 2000. Pembangunan Ekonomi di Dunia Ketiga. Jakarta: Erlangga.

Todaro, Michael P dan Stephen C. Smith (2008). Pembangunan Ekonomi. Edisi kesembilan. Jakarta: Erlangga.

Todaro, M.P. 2011. Pembangunan Ekonomi. Edisi Kesebelas. Jakarta: Penerbit Erlangga

Todaro, Michael P. and Smith, Stephen C. 2011. Economic Development. Eleventh Edition. United States: Addison Wesley. 